\title{
Szociodemográfiai hatótényezők vizsgálata unipoláris major depresszió kezelésében egy utánkövetéses klinikai vizsgálatban
}

\author{
Ferencz Melinda dr. ${ }^{1,3}$ - Csibi Sándor dr. ${ }^{2}$ - Gabos Grecu József dr., ${ }^{1,3}$ \\ Marosvásárhelyi Orvosi és Gyógyszerészeti Egyetem, ${ }^{1}$ Pszichiátria Tanszék, \\ ${ }^{2}$ Etika és Társadalomtudományok Tanszék, Marosvásárhely, Románia \\ ${ }^{3} 1$. Sz. Pszichiátriai Klinika, Marosvásárhely, Románia
}

Bevezetés: A depresszió korunk egyik legelterjedtebb megbetegedése, jelenleg több mint 300 millió embert érint világszerte. A depresszió kialakulásában és lefolyásában több szociodemográfiai kockázati tényező van hatással. Célkitüzés: A klinikailag diagnosztizált unipoláris major depresszió kezelésében és remissziójában szerepet játszó szociodemográfiai tényezók vizsgálata.

Módszer: Az adatgyújtés 2016-ban történt, a marosvásárhelyi 1. Sz. Pszichiátriai Klinikán, a résztvevők az év folyamán, jelentősebb komorbid fizikai vagy más pszichiátriai zavar nélkül regisztrált páciensek voltak. A szociodemográfiai tényezők vizsgálatára önkitöltős saját kérdőívet alkalmaztunk, amely nem, életkor, lakókörnyezet, iskolai végzettség, családi állapot, foglalkoztatottság és munka nélkül eltöltött időszak változóit mérte fel. Az unipoláris major depresszió diagnózis megállapításában a DSM-5, a súlyosság értékelésében és állapotkövetésre a Hamilton Depreszszió Skála 17 tételes magyar változatát alkalmaztuk. A minta életkor szerinti eloszlása 18-65 év közötti felnőtt, 44 férfi $(28,9 \%)$ és 108 nő $(71,1 \%)$; 66 fekvő- és 86 járóbeteg. A páciensek 12 héten keresztül gyógyszeres kezelést kaptak, és HAM-D-17-tesztelésen vettek részt beutaláskor, nyolc és 12 hét után.

Eredmények: A terápia hatására a depresszióskálán elért pontszámok jelentősen csökkentek a nyolc hét, valamint a 12 hét kezelés után. A nem, az életkor és a lakókörnyezet nem befolyásolta a kezelést, de a felsőfokú végzettséggel rendelkező betegeknél a kezelés végén a depressziós tünetek kisebb mértékben voltak kimutathatóak. A házas betegek depressziópontszámai kisebbek voltak, mint a nem házas betegeké, az alkalmazottaké pedig kisebbek, mint a tartósan munka nélkülieké.

Következtetés: Az unipoláris major depresszió SSRI-kezelésének eredményességét a családi állapot és foglalkoztatottság a remisszió prediktoraiként jelentősen befolyásolták, így ezekben az esetekben a pszichoterápiás beavatkozás szükségessége javasolt.

Orv Hetil. 2017; 158(43): 1715-1722.

Kulcsszavak: unipoláris major depresszió, szociodemográfiai kockázati tényezők, remisszió

\section{Study of socio-demographic factors in the treatment of unipolar major depression in a follow-up clinical trial}

Introduction: Depression is one of the most widespread illnesses of our time, currently affecting more than 300 million people worldwide. Literature identifies several socio-demographic risk factors in the development of the depression.

Aim: We aim to examine the socio-demographic factors involved in the remission of clinically diagnosed unipolar major depression.

Method: Data collection was performed during 2016, at the 1st Psychiatric Clinic from Tirgu Mures. Participants were patients reporting no other physical or psychiatric disorder. Self-reporting questionnaire assessed socio-demographic factors, such as gender, age, neighborhood, education, marital status, employment, and unemployed period. DSM-5 criteria were used in diagnosis, and the severity and status tracking was assessed with the 17-item version of the Hamilton Depression Scale. The age distribution of the sample was between 18-65 years of age, 44 male $(28.9 \%)$ and 108 female (71.1\%), 66 inpatients and 86 outpatients. Patients received medication for 12 weeks, and were involved in HAM-D 17 testing when hospitalized, at 8 and 12 weeks. 
Results: Scores of depression decreased significantly after 8 and 12 weeks of the treatment. Gender, age, and neighborhood did not influence the treatment, but patients with high education manifested less depressive symptoms at the end of treatment. Among married patients depression score was lower than among unmarried, and employees showed lower depression scores comparing to long-term unemployed patients.

Conclusion: Marital status and employment were relevant predictors of remission, proving a significant effect on the treatment outcomes. Thus, psychotherapeutic intervention is recommendable in the case of single and unemployed patients.

Keywords: major unipolar depression, socio-demographic risk factors, remission

Ferencz M, Csibi S, Gabos Grecu J. [Study of socio-demographic factors in the treatment of unipolar major depression in a follow-up clinical trial]. Orv Hetil. 2017; 158(43): 1715-1722.

(Beérkezett: 2017. augusztus 8.; elfogadva: 2017. szeptember 12.)

\section{Rövidítések}

ATR $=($ antidepressant treatment response $)$ antidepresszáns kezelési válasz; $\mathrm{BMI}=($ body mass index $)$ testtömegindex; DSM$5=$ (Diagnostic and Statistical Manual of Mental Disorders) A mentális betegségek diagnosztikai és statisztikai kézikönyve; HAM-D = (Hamilton Rating Scale for Depression) Hamilton Depresszió Skála; MDD = major depression disorder; QEEG = (quantitative electroencephalography) frontális kvantitatív elektroencefalográfia; SSRI $=$ (selective serotonin reuptake inhibitors) szelektív szerotoninújrafelvétel-gátlók; WHO = (World Health Organization) Egészségügyi Világszervezet

Az Egészségügyi Világszervezet (WHO) szerint a depresszió korunk egyik legelterjedtebb megbetegedése, jelenleg több mint 300 millió embert érint világszerte, ami a világ lakosságának $4,4 \%$-át jelenti, és ez a szám évente folyamatosan emelkedik. A depresszió előfordulási aránya Romániában 5\%, ami 931842 diagnosztizált esetet jelent [1]. A depresszió rendkívüli mértékú hatást gyakorol az egészségi állapot romlására. Az Egészségügyi Világszervezet rangsorolásában a depressziót azon legjelentősebb faktorok közé sorolják, amely hozzájárul az általános munkaképtelenség kialakulásához. A depreszszió ugyanakkor a leginkább meghatározó tényezője az öngyilkosság okozta haláleseteknek, a statisztikák közel 800000 esetről számolnak be évente [1]. Magyarországon az öngyilkossági arány továbbra is a második legmagasabb az Európai Unióban [2].

A depresszió kialakulásában több szociodemográfiai és pszichoszociális tényező is részt vesz. A legtöbb kockázati tényező szignifikáns társulást mutat a depresszióval az egész élettartam alatt, de a kutatások szerint öt kockázati tényező esetében a társulás ereje az életkortól függött. Így a fiatalkori depresszió specifikus faktorai a gyermekkori visszaélések, a fájdalom, a testtömegindex (BMI) és a krónikus betegségek száma, az idősebb kor számára pedig az alacsony jövedelem [3]. Emellett a kevésbé fejlett országokban a depresszió előfordulása magasabb. A szegényebb populáció körében magasabb a pszichológiai distressz előfordulása, míg a magasabb be- vételü népesség körében alacsonyabb a depresszió kezelésének aránya [4].

A nem és a depresszió közötti összefüggéseket elemezve Twenge és Nolen-Hoeksema kimutatták, hogy a lányok depressziós tüneteinek száma meglehetősen stabil volt egészen 12 éves korig, ezután a tünetek számának növekedését észlelték. A fiúk depressziós tüneteinek száma viszont az életkortól függetlenül azonos szinten maradt [5]. Az egyetemi évek alatt a depresszió szintje jelentősen magasabb, különösen az első egyetemi évben, mindkét nem esetében [6]. Később a depresszió előfordulási aránya magasabb a nók esetében [7], de az arány évente csökken, majd a 75 év feletti korosztály esetében teljesen eltünik [8].

A házassági állapot befolyását tekintve a depresszió előfordulási arányára jellemző, hogy az egyedülálló, nem házasok körében (sosem voltak házasok, elváltak vagy özvegyek) közel kétszer akkora depresszió-előfordulási kockázat figyelhető meg, mint a házasságban élók között. A nem házas állapotot újabb kutatások tartós depresszív rendellenességgel társították [9]. A munkanélküliség tovább növeli a kockázatát a depresszív megbetegedésnek [10]. Az egészségügyi alkalmazottak körében a depresszió a munkahelyi elégedettséggel, a betegségek számával és a pszichés jólléttel volt szoros kapcsolatban [11].

A foglalkoztatás, a részmunkaidős foglalkoztatás és a teljes munkaidős foglalkoztatás a munkanélküliséghez képest szignifikáns összefüggést mutatott a terhesség alatti depressziós tünetek alacsonyabb elófordulásával [12]. A funkcionális állapot fontos mutatója a depressziónak, így amikor a depressziós betegek teljes remissziót érnek el, képesek visszaállítani a betegség előtti pszichoszociális funkció státuszát, valamint rendszeres társadalmi tevékenységeken vesznek részt, és céltudatosabbak a depresszió kezelésében [13]. A klinikai választ gyakran úgy definiáljuk, mint legalább 50\%-os csökkenés egy adott tüneti skálán, ez az eredmény azt sugallja, hogy a remissziós állapot klinikailag fontos javulást jelez a munka múködésében és a termelékenységben [14]. 
1. táblázat |A minta eloszlása és összefüggéseik a szociodemográfiai változók mentén

\begin{tabular}{|c|c|c|c|c|c|}
\hline Változók & Csoportok & Fekvőbeteg (n = 66) & Járóbeteg $(\mathrm{n}=86)$ & $\chi^{2}$ & Szignifikancia \\
\hline \multirow[t]{2}{*}{ Nem } & Férfi & 26 & 18 & \multirow{2}{*}{6,18} & \multirow{2}{*}{0,01} \\
\hline & Nő & 40 & 68 & & \\
\hline \multirow[t]{3}{*}{ Életkor } & 18-35 év között & 21 & 7 & \multirow{3}{*}{26,18} & \multirow{3}{*}{$<0,01$} \\
\hline & 35-50 év között & 36 & 37 & & \\
\hline & 51-65 év között & 9 & 42 & & \\
\hline \multirow[t]{2}{*}{ Lakókörnyezet } & Városi & 27 & 35 & \multirow{2}{*}{0,01} & \multirow{2}{*}{0,55} \\
\hline & Vidéki & 39 & 51 & & \\
\hline \multirow[t]{4}{*}{ Iskolázottság } & 4 osztály & 10 & 7 & \multirow{4}{*}{5,73} & \multirow{4}{*}{0,12} \\
\hline & 8 osztály & 13 & 26 & & \\
\hline & 12 osztály & 32 & 46 & & \\
\hline & Egyetem & 11 & 7 & & \\
\hline \multirow[t]{3}{*}{ Családi állapot } & Házas & 47 & 57 & \multirow{3}{*}{0,69} & \multirow{3}{*}{0,70} \\
\hline & Egyedülálló & 8 & 10 & & \\
\hline & Elvált & 11 & 19 & & \\
\hline \multirow[t]{2}{*}{ Foglalkoztatottság } & Alkalmazott & 26 & 37 & \multirow{2}{*}{0,25} & \multirow{2}{*}{0,65} \\
\hline & Munkanélküli & 40 & 49 & & \\
\hline
\end{tabular}

A háziorvosok [15] és a klinikai szakemberek tevékenységében egyaránt fontos szerepet tölt be az MDDbetegek támogatása a depresszió tüneteinek leküzdésében vagy ellenőrzésében, a depresszió elmélyülésének figyelmeztető jeleinek felismerésében, valamint a betegek bizalmának növelésében a saját életük és betegségeik kezelésében [16].

Célunk a klinikailag diagnosztizált unipoláris major depresszió kezelésében és remissziójában szerepet játszó szociodemográfiai tényezők vizsgálata. Feltételezésünk szerint az életkor, az iskolai végzettség, úgymint a lakóközösséghez tartozás, a családi állapot, a foglalkoztatottság közrejátszanak a terápia hatékonyságának emelésében és a depresszió tartós visszaszorításában. Így a magasabb iskolai végzettséggel rendelkező, a házas, az

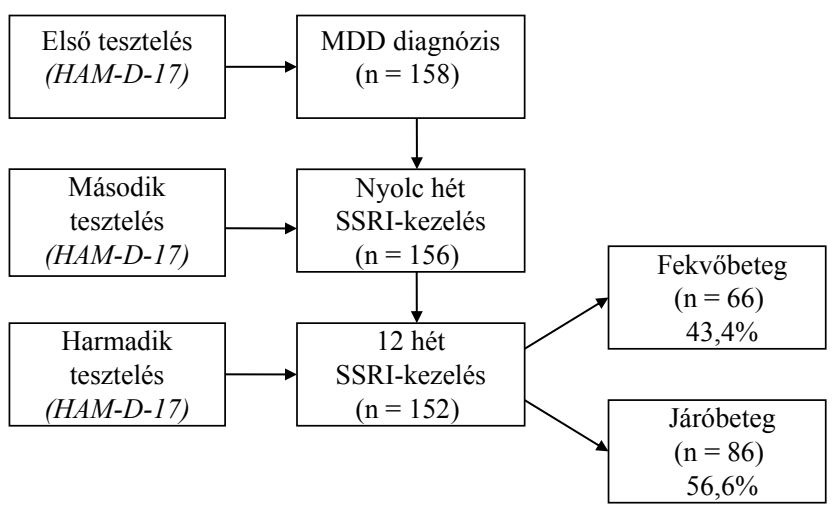

1. ábra

| A kutatás lépései és a minta eloszlása a klinikai státusz szerint alkalmazott vagy rövidebb ideje munkanélküli páciensek kisebb HAM-D-17-pontszámmal és kevesebb depressziós tünettel jellemezhetók a 12 hetes SSRI-kezelés után.

\section{Módszer}

\section{Minta}

A kutatásban eredetileg 158, unipoláris major depresszióval diagnosztizált páciens vett részt, majd az első tesztelés után kettő, a második tesztelés után négy páciens nem kívánt részt venni a további felmérésben, így a végleges minta 152 páciensből állt (1. ábra).

A résztvevők közé kizárólag a DSM-5 kritériumai szerint MDD-vel diagnosztizált, jelentősebb komorbid fizikai vagy más pszichiátriai zavar nélküli páciens került. A minta életkor szerinti eloszlása 18-65 év közötti felnőtt (18,4\% 18-35 év között, 48\% 35-50 év között és 33,6\% 50-65 év között), 44 férfi (28,9\%) és 108 nő $(71,1 \%)$. A csoportok arányai közötti különbségeket $\chi^{2}$ teszttel vizsgáltuk és a szignifikanciaszintet is feltüntettük (1. táblázat).

A klinikai státusz formája szerint 66 fekvőbeteg ${ }^{1}$ (26 férfi és 40 nő) és 86 járóbeteg ${ }^{2}$ ( 18 férfi és 68 nő) vett részt a kutatásban. A fekvőbetegek $(\mathrm{n}=66)$ egy része a beutalás előtt öngyilkossági kísérletet tett $(\mathrm{n}=35,53 \%)$ a következő módon: gyógyszer-túladagolás (nyolc férfi, 17 nő), akasztás (hét férfi), érfelvágás (három nő).

${ }^{1}$ Angol szakirodalomban: inpatients.

${ }^{2}$ Angol szakirodalomban: outpatients. 


\section{Eszközök}

Az MDD-súlyosság értékelésében és állapotkövetésre a Hamilton Depresszió Skála 17 tételes magyar változatát alkalmaztuk (Hamilton Rating Scale for Depression HAM-D-17 [17-19]). A HAM-D 17 tételes verziójának pontszámai 0-tól 52-ig terjednek, a magasabb pontszám a depresszió súlyosságát jelenti. A HAM-D értékelése szerint a 0-7 pontszám nem jelent depressziót, a 8-16 pontszám könnyü, a 17-23 közepes szintű és a 24 feletti pontszám pedig súlyos depressziót mutat [20]. Mintánkban a skála Chronbach-alfa-értéke 0,83 volt, ami jónak tekinthető. A szociodemográfiai tényezők vizsgálatára önkitöltős saját kérdőívet alkalmaztunk. A kérdőív a nem, az életkor, a lakókörnyezet, az iskolai végzettség, a családi állapot, a foglalkoztatottság és a munka nélkül eltöltött időszak változóinak adatait mérte fel.

Az adatgyújtés 2016-ban történt, a marosvásárhelyi 1. Sz. Pszichiátriai Klinikán, a Marosvásárhelyi Orvosi és Gyógyszerészeti Egyetem Kutatásetikai Bizottsága engedélyével (15915/2015). A páciensek kutatásban való részvételét tájékozott beleegyezés előzte meg. Az első alkalom során megtörtént a szűrővizsgálat, a résztvevők tájékozott beleegyezése, a demográfiai adatok rögzítése és a HAM-D-17 első felvétele. Ezt követően a páciensek 12 héten keresztül gyógyszeres kezelést kaptak (szelektív szerotoninújrafelvétel-gátlókat - SSRI), pszichoterápia nélkül. A gyógyszeres terápiát anxiolyticum és altató társításával egészítettük ki a kezelés második-negyedik hetében, abban az esetben, ha szorongás és alvászavar volt jelen. Nyolchetes állapotkövetés után, valamint a kezelés befejezésekor újabb HAM-D-17-adatrögzítésre került sor.

A HAM-D-17 szenzitíven reagál a javulás állapotára [19]. A tünetek jelenlétét a 3-tól 5-ig terjedő válaszok határozzák meg, súlyossági szintjüket és intenzitásukat az orvosok a betegek reakcióiban és megfigyeléseiben támasztják alá. A $\leq 6$ pontszámok [21], újabb kutatások szerint pedig a $\leq 7$ pontszámok [22] remissziót mutatnak, így a betegek tünetmentességét és a megszokott pszichoszociális tevékenységeikhez való visszatérését jelzik. A kezelés során a kiindulási értékek $\leq 50 \%$ vagy azt meghaladó csökkenését tekintik a klinikai válasz mutatójának, más szóval klinikailag jelentős változásnak [22].

\section{Statisztikai elemzés}

Az adatok statisztikai feldolgozása az SPSS programcsalád (SPSS, Inc., Chicago, IL, Amerikai Egyesült Államok) 20 verziójával történt. Az elemzés deskriptív statisztikai eszközökkel (medián, átlag, minimum-maximum érték, százalékok), az összefüggések kimutatása $\chi^{2}$ teszttel vagy Fisher-teszttel történt. A teszteredmények közötti különbségeket kétváltozós t-teszttel, varianciaanalízissel (ANOVA), Bonferroni-teszttel vagy esetenként egyváltozós t-teszttel elemeztük. A változók előrejelző szerepét bináris logisztikus regresszióelemzéssel mutattuk ki.
2. táblázat |A HAM-D-17-skálán elért pontszámok elemzése a terápia három időpontjában (kétváltozós t-teszt)

\begin{tabular}{llccccc}
\hline HAM-D-17 & $\mathrm{n}$ & Átlag & Szórás & $\mathrm{t}$ & $\mathrm{p}$ \\
\hline 1 & Beutaláskor - & 152 & 25,01 & 0,92 & & \\
& 8 hét után & 152 & 16,48 & 3,00 & & \\
\hline 2 & 8 hét után - & 152 & 16,48 & 3,00 & \multirow{2}{*}{26,66} & $<0,01$ \\
& 12 hét után & 152 & 10,92 & 3,80 & & \\
\hline 3 & Beutaláskor - & 152 & 25,01 & 0,92 & & \\
& 12 hét után & 152 & 10,92 & 3,80 & & \\
\hline
\end{tabular}

\section{Eredmények}

\section{A nyolchetes és a 12 betes SSRI-terápia batékonynak bizonyult az unipoláris major depresszió kezelésében}

Az első lépésben a terápia hatékonyságát elemeztük a teljes mintában, a három időpontban (első szûrés, nyolc hét után, 12 hét után) rögzített depresszióteszt-eredmények összehasonlítása által (2. táblázat). Eredményeink szerint a depresszióskálán elért pontszámok jelentősen csökkennek a nyolc hét, valamint a 12 hét kezelés után.

\section{A fekvőbetegek a kezelés után alacsonyabb pontszámokat értek el, mint a járóbetegek}

A klinikai státusz formáját illetően a fekvőbetegek és a járóbetegek HAM-D-17-pontszáma a beutalás időpontjában megegyezik, majd a nyolc hét, valamint a 12 hét utáni pontszámok jelentősen különböznek a két kategória között (3. táblázat).

\section{A felsôfokú végzettség, a családi állapot (házas) és a foglalkoztatottság (alkalmazott) mintánkban befolyásolta a terápia batékonyságát}

A következőkben a SSRI-terápia hatékonyságát elemeztük a pszichoszociális változók függvényében (3. táblázat). A depresszióskála pontszámai a beutalásnál hasonló szintúek a fekvőbetegeknél és a járóbetegeknél, de a nyolchetes kezelés után a fekvőbetegeknél jelentősebb mértékben csökkennek, és ez a szignifikáns pontszámbeli különbség a 12 hetes kezelés végén is fennmarad. Adataink szerint a HAM-D-17 pontszámai nem különböztek szignifikánsan a nem, az életkor és a lakókörnyezet függvényében egyik adatfelvétel során sem. A felsőfokú végzettséggel rendelkező betegeknél a kezelés végén a depressziós tünetek kisebb mértékben voltak kimutathatóak, mint az elemi, illetve középiskolát végzettek körében (2. ábra).

A házas betegek depressziópontszámai kisebbek voltak, mint a nem házas betegeké, mind a nyolchetes, mind 
3. táblázat |A HAM-D-17-skálán elért pontszámok elemzése a terápia három időpontjában, a klinikai státusz formája, valamint a szociodemográfiai változók függvényében (egyváltozós t-teszt)

\begin{tabular}{|c|c|c|c|c|c|c|c|}
\hline \multirow{3}{*}{$\begin{array}{l}\text { Változók } \\
\text { Klinikai státusz }\end{array}$} & \multirow{2}{*}{$\begin{array}{l}\text { Csoportok } \\
\text { (elemszám) } \\
\text { Fekvőbeteg }(66)\end{array}$} & \multicolumn{2}{|c|}{$\begin{array}{l}\text { Beutaláskor } \\
\text { (átlag, p-érték) }\end{array}$} & \multicolumn{2}{|c|}{$\begin{array}{c}8 \text { hét után } \\
\text { (átlag, p-érték) }\end{array}$} & \multicolumn{2}{|c|}{$\begin{array}{l}12 \text { hét után } \\
\text { (átlag, p-érték) }\end{array}$} \\
\hline & & 24,96 & \multirow{2}{*}{0,61} & 15,63 & \multirow{2}{*}{0,01} & 10,27 & \multirow{2}{*}{0,05} \\
\hline & Járóbeteg (86) & 25,04 & & 17,12 & & 11,41 & \\
\hline \multirow[t]{2}{*}{ Nem } & Férfi (44) & 25,09 & \multirow{2}{*}{0,51} & 16,61 & \multirow{2}{*}{0,72} & 10,72 & \multirow{2}{*}{0,69} \\
\hline & Nő (108) & 24,98 & & 16,42 & & 11,00 & \\
\hline \multirow[t]{3}{*}{ Életkor ${ }^{3}$} & 18-35 év között (28) & 24,85 & \multirow{3}{*}{0,41} & 16,39 & \multirow{3}{*}{0,60} & 11,10 & \multirow{3}{*}{0,89} \\
\hline & 35-50 év között (73) & 24,98 & & 16,27 & & 10,76 & \\
\hline & 51-65 év között (5l) & 25,13 & & 16,82 & & 11,03 & \\
\hline \multirow[t]{2}{*}{ Lakókörnyezet } & Városi (62) & 25,01 & \multirow{2}{*}{0,97} & 16,90 & \multirow{2}{*}{0,15} & 11,12 & \multirow{2}{*}{0,57} \\
\hline & Vidéki (90) & 25,01 & & 16,18 & & 10,77 & \\
\hline \multirow[t]{3}{*}{ Iskolázottság } & Elemi (56) & 24,85 & \multirow{3}{*}{0,04} & 16,30 & \multirow{3}{*}{0,65} & 10,96 & \multirow{3}{*}{0,05} \\
\hline & Középiskola (78) & 25,19 & & 16,47 & & 11,34 & \\
\hline & Egyetem (18) & 24,72 & & 17,05 & & 8,94 & \\
\hline \multirow[t]{2}{*}{ Családi állapot } & Házas (104) & 24,93 & \multirow{2}{*}{0,11} & 16,12 & \multirow{2}{*}{0,03} & 10,25 & \multirow{2}{*}{$<0,01$} \\
\hline & Nem házas ${ }^{1}(48)$ & 25,18 & & 17,25 & & 12,35 & \\
\hline \multirow[t]{4}{*}{ Foglalkoztatottság ${ }^{3}$} & Alkalmazott (63) & 24,57 & & 14,95 & & 9,26 & \\
\hline & <2 éve munkanélküli² (22) & 25,13 & 0,04 & 16,22 & 0,28 & 10,81 & 0,45 \\
\hline & 1-2 éve munkanélküli² (33) & 25,27 & $<0,01$ & 16,93 & $<0,01$ & 11,75 & $<0,01$ \\
\hline & >2 éve munkanélküli² ${ }^{2}(34)$ & 25,50 & $<0,01$ & 19,02 & $<0,01$ & 13,23 & $<0,01$ \\
\hline
\end{tabular}

${ }^{1} \mathrm{Az}$ egyedülálló és az elvált kategóriák összevonásából alkotva.

${ }^{2} \mathrm{~A}$ munkanélküli kategória eloszlásából alkotva.

${ }^{3}$ ANOVA varianciaanalízis, Bonferroni-teszt alkalmazásával.

a 12 hetes kezelés után. A legkisebb HAM-D-pontszámok az alkalmazottak között voltak kimutathatóak (átlag: 9,26), majd ezek a munkanélküliség idejével arányosan emelkedtek mindhárom adatfelvétel során (3. ábra).

\section{A páciensek családi és foglalkoztatottsági állapota mintánkban a remisszió prediktorai voltak}

A változók dihotomizálása után bináris logisztikus regressziós modellt állítottunk össze, amelyben a függő változó a 12 hetes kezelés utáni remisszió elérése volt ( 1 . csoport - 7 alatti HAM-D-17 pontszámok és 2. csoport - 7 feletti pontszámok). A független változók az iskolai végzettség, a házassági helyzet, a foglalkoztatottság és az öngyilkosság kísérlete voltak (4. táblázat). A regressziós modell szerint a remisszió szignifikáns mértékben függ a páciensek családi állapotától $(\mathrm{OR}=0,13,95 \%$-os $\mathrm{CI}=$ $0,02-0,66)$ és foglalkoztatottságától $(\mathrm{OR}=0,24,95 \%$ os $=0,06-0,98)$.

\section{Megbeszélés}

Az SSRI-kezelés hatékonysága az unipoláris major depresszió esetében mintánkban is beigazolódott a terápia mindkét szakaszában. Így a HAM-D-17 skálán elért pontszámok jelentősen csökkentek nyolc hét kezelés után, majd az újabb négy hét kezelés következtében. A beutalás és a kezelés befejezése között a depresszióskálán elért pontszámok átlaga több mint $60 \%$-kal csökkent, tehát remissziót mutattak. A skálán elért pontszámok szignifikánsan alacsonyabbak voltak a fekvőbetegeknél, mint a járóbetegeknél, így esetükben az SSRI-kezelés hatékonyabb volt. Eredményeink egybehangzóak a Balestri és mtsai által kimutatott összefüggésekkel [23]. A szerzók a járóbetegek esetében a kezelés hatékonyságát a saját környezetükbe való visszatérés befolyásával magyarázzák.

A szociodemográfiai változók elemzése a nem, az életkor és a lakókörnyezet tekintetében, a kezelés hatékonyságát illetően nem mutatott ki jelentős különbözőségeket. A kutatások szerint a nem prediktív szerepe nem volt kimutatható a kezelésre való válasz, valamint a kezelés eredményessége tekintetében sem [24]. Egy másik kutatásban viszont az életkor és a testtömeg a depresszió remissziójának prediktorai voltak [25].

Eredményeink kimutatták, hogy a családi állapot befolyásolja a kezelés hatékonyságát. Mintánkban a házas betegek szignifikánsan kisebb pontszámot értek el a nyolc- és a 12 hetes kezelés után, mint a nem házas (egyedülálló vagy elvált) betegek, annak ellenére, hogy a beutalás időpontjában mindkét kategória pontszáma hasonló volt. Adataink összhangban vannak a legújabb ku- 


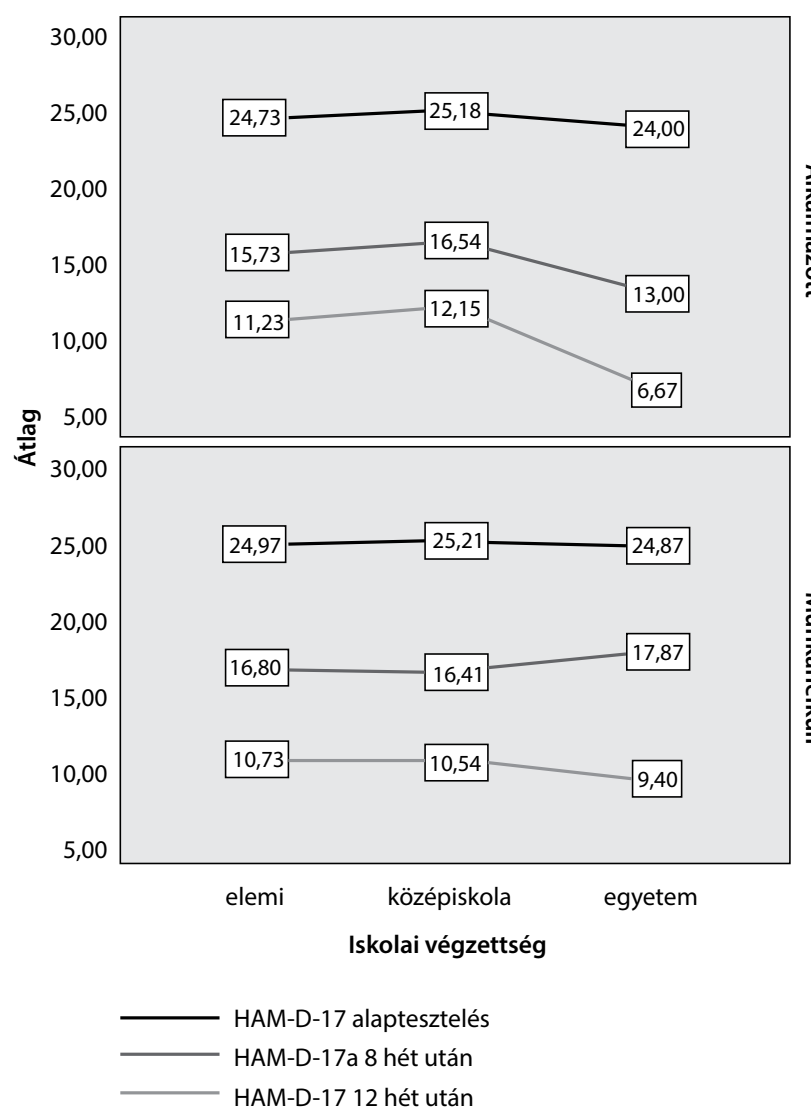

2. ábra

A három tesztelés pontszámainak alakulása a foglalkoztatottság és az iskolai végzettség függvényében

tatási eredményekkel, amelyek szerint a családi állapot összefügg a depressziós tünetek csökkenésével [26], ugyanakkor a családi állapot (házas vagy együttélés) a jobb kezelésre adott válasz előrejelzője, az egyedül élőkkel (egyedülállók, elváltak, özvegyek) szemben [27]. Úgy tűnik, a családi állapot a nonremisszió védőfaktoraként múködik [28].

Adataink szerint a foglalkoztatottság jelentősen befolyásolja a kezelésre adott választ és a kezelés eredményességét. Az alkalmazottak és a munkanélküliek HAM-D-

4. táblázat |A 12 hét kezelés után jelentkező remisszió bináris logisztikus modellje

\begin{tabular}{|c|c|c|c|c|c|c|c|}
\hline & \multirow[t]{2}{*}{ B } & \multirow{2}{*}{$\begin{array}{l}\text { Stan- } \\
\text { dard } \\
\text { hiba }\end{array}$} & \multirow[t]{2}{*}{ Wald } & \multirow{2}{*}{$\begin{array}{l}\text { Szigni- } \\
\text { fikancia }\end{array}$} & \multirow[t]{2}{*}{$\mathrm{OR}^{1}$} & \multicolumn{2}{|c|}{$95 \%$-os $\mathrm{CI}^{2}$} \\
\hline & & & & & & Alsó & Felső \\
\hline $\begin{array}{l}\text { Iskolai } \\
\text { végzettség }\end{array}$ & 0,45 & 0,80 & 0,31 & 0,57 & 1,57 & 0,32 & 7,62 \\
\hline Családi állapot & 0,88 & 0,45 & 3,86 & 0,04 & 2,42 & 1,00 & 5,86 \\
\hline $\begin{array}{l}\text { Foglalkozta- } \\
\text { tottság }\end{array}$ & 1,42 & 0,70 & 4,09 & 0,04 & 4,14 & 1,04 & 16,47 \\
\hline $\begin{array}{l}\text { Öngyilkossági } \\
\text { kísérlet }\end{array}$ & $-1,03$ & 0,62 & 2,79 & 0,09 & 0,35 & 0,10 & 1,19 \\
\hline Konstans & $-3,57$ & 1,21 & 8,58 & 0,01 & 0,02 & & \\
\hline
\end{tabular}

${ }^{1}$ Odds ratio: esélyhányados.

${ }^{2} \mathrm{Az}$ esélyhányados 95\%-os konfidenciaintervalluma.

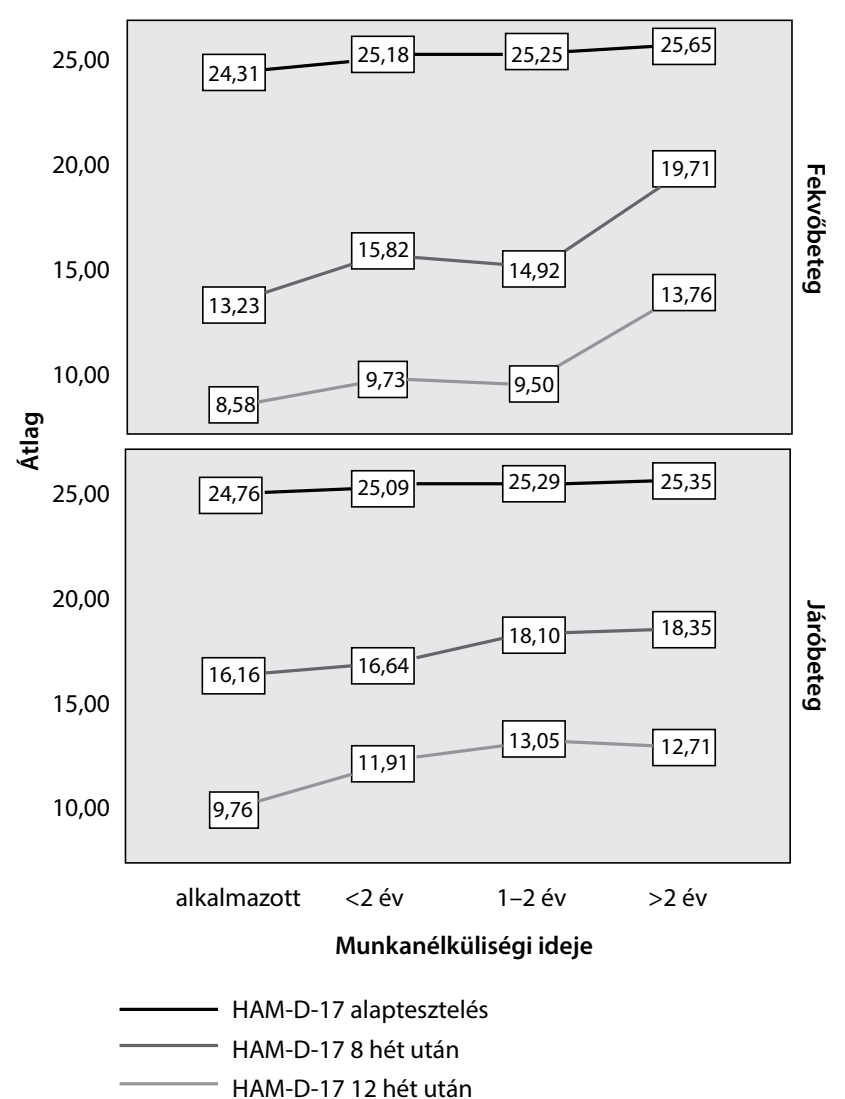

3. ábra

A három tesztelés pontszámainak alakulása a klinikai státusz és a munkanélküliség tartama függvényében

17-pontszámai közötti összehasonlítása szignifikáns különbségeket mutatott az alkalmazottak javára a kezelés hatékonyságát illetően. Tovább elemezve a munkanélküliség idejét és a kezelés után elért depresszió-pontszámokat, az alkalmazottak és a több mint két éve munkanélküliek között jelentős különbségeket találtunk. Így nyolc hét SSRI-kezelés után a remisszió mértéke jelentősebb az alkalmazottak körében, és ez a különbség a teljes kezelés után is fennmaradt. Úgy tünik, hogy a munkanélküliség ideje a kezelés hatékonyságát és a remisszió mértékét is szignifikánsan befolyásolja. A kutatások alapos bizonyítékot találtak a depressziós epizód hosszú időtartama és a munkanélküliség között [29]. A rendszeres részidős munkát végző férfiaknál több depressziós tünetet észleltek; a nők hasonló tüneteket mutattak, ha munkahelyükön marginalizáltak voltak. Azok a férfiak és nők, akiknek a munkahelyi befolyásuk alacsony volt, nagyobb kockázatot mutattak a depressziós tünetek kialakulása tekintetében [30]. Hazai eredmények szerint a munkavállalók csoportjánál a munka értelmessége, a munkahelyi elkötelezettség és a fejlődési lehetőségek csökkentették a depresszív tünetek jelenlétének előfordulását [31]. Stankunas és mtsai eredményei kimutatták, hogy a tartósan munkanélküliek több depressziós hangulatot szenvedtek el az elmúlt 12 hónapban, mint a rövid távon munka nélküliek. Adataik szerint a munkanélküliség idő- 
tartamának és a Beck Depresszió Skála-pontszámoknak pozitív korrelációja volt [32].

Az iskolai végzettség szintje jelentősen összefügg a kezelés után elért HAM-D-17-pontszámokkal és a remiszszió mértékével, és ez a tendencia érvényes a munkanélkülieknél és az alkalmazottaknál egyaránt. Kutatásunkban az alkalmazottak kisebb pontszámot értek el a nyolc hét, valamint a 12 hét kezelés következtében, mint a munkanélküliek, tehát a remisszió mértéke is jelentósebb. Adataink összefüggenek a korábbi kutatások eredményeivel, amelyek kimutatták, hogy a felsőfokú végzettség és a jövedelem olyan tényezők, amelyek jelentősen csökkentik a depresszió kialakulásának kockázatát [32].

A kutatók szerint az antidepresszánsokkal való kezelés a súlyos depresszív rendellenességek esetében csak 33\%ban hatékony a tüneti remisszió elérésében az első kezelésben részesülő betegek esetében [33]. A funkcionális státusz a depresszió remissziójának klinikai prediktora volt hat hónapos kezelés után, és a funkcionális státusz javulása nagymértékben korrelált a klinikai remisszióval [13]. A betegek megfelelő pszichoszociális múködése és önhatékonyságuk fokozása fontos tényezője volt a teljes remisszió elérésének [16]. A házassági problémák proaktív kezelése a klinikai környezetben segíthet a pszichoszociális „heg” minimalizálásában, amely összefüggésben van a súlyos depresszióval [34]. Iniesta és mtsai szerint a demográfiai és klinikai változók kombinációja előre jelzi a remissziót [25]. Így a kérdőívek és a besorolási skálák információi, valamint kéttípusú antidepreszszáns kezelés jelentősen hozzájárulnak az egyes betegek kezelési kimenetelének előrejelzéséhez.

Kutatásunk egyik gyenge pontja lehet, hogy a remiszsziót kizárólag a HAM-D-17 pontszámainak változásai mutatják, valamint, hogy adataink egyetlen klinikáról származnak. Egyes kutatások szerint a remisszió megbízhatóbb előrejelzője a frontális kvantitatív elektroencefalográfiás (QEEG) biomarker és az antidepresszáns kezelési válasz (ATR) index [35]. Ugyanakkor megemlítjük, hogy mintánk nem tekinthető országos szinten reprezentatívnak.

Erôsségként kiemeljük az utánkövetéses vizsgálati módszer alkalmazását, a családi állapot, a foglalkoztatottság, a munkanélküliségi idő és a klinikai remisszió közötti összefüggések tisztázását.

\section{Következtetés}

$\mathrm{Az}$ unipoláris major depresszió SSRI-kezelésének eredményességét az egyéni és a szociodemográfiai tényezők jelentős módon befolyásolják. Közülük a családi állapot és foglalkoztatottság a remisszió prediktoraiként jelentősek és pszichés hatásaiknak előzetes pszichoterápiás korrigálása, kezelése ajánlott.
Anyagi támogatás: A közlemény megírása nem részesült anyagi támogatásban.

Szerzői munkamegosztás: F. M.: Az alapkoncepció kidolgozása, adatgyưjtés és a bevezető rész megírása. Cs. S.: A módszertan kidolgozása, statisztikai elemzés és az eredmények bemutatása. G. G. J.: Szakmai konzultáció, a kézirat javítása, a megbeszélés megírása. A cikk végleges változatát valamennyi szerző jóváhagyta.

Érdekeltségek: A szerzőknek nincsenek érdekeltségeik.

\section{Irodalom}

[1] WHO. Depression and other common mental disorders: global health estimates. World Health Organization, Geneva; 2017. Available from: http://www.who.int/mental_health/ management/depression/prevalence_global_health_estimates/en/ [accessed: July 31, 2017].

[2] Rihmer Z, Döme P, Gonda X. 30 years against suicide: a summary of our research on depression and suicide prevention between 1985 and 2015. [30 év az öngyilkosság ellen: Munkacsoportunk depresszió- és szuicidprevenciós kutatásainak összefoglalása - 1985-2015.] Neuropsychopharmacol Hung. 2015; 17: 113-119. [Hungarian]

[3] Schaakxs R, Comijs HC, van der Mast RC, et al. Risk factors for depression: differential across age? Am J Geriatr Psychiatry 2017; 25: 966-977.

[4] Fukuda Y, Hiyoshi A. Influences of income and employment on psychological distress and depression treatment in Japanese adults. Environ Health Prev Med. 2012; 17: 10-17.

[5] Twenge JM, Nolen-Hoeksema S. Age, gender, race, socioeconomic status, and birth cohort difference on the children's depression inventory: A meta-analysis. J Abnorm Psychol. 2002; 111: 578-588.

[6] Bayram N, Bilgel N. The prevalence and socio-demographic correlations of depression, anxiety and stress among a group of university students. Soc Psychiatry Psychiatr Epidemiol. 2008; 43: 667-672.

[7] Szemán-Nagy A. The examination of gender differences in depression in connection with alexithymia, focusing on male depression. [Nemi különbségek vizsgálata a depressziós tünetegyüttesben az alexitímia mentén, különös tekintettel a férfi depresszióra.] Magyar Pszichológiai Szemle 2014; 69: 319-336. [Hungarian]

[8] Patten SB, Williams JV, Lavorato DH, et al. The association between major depression prevalence and sex becomes weaker with age. Soc Psychiatry Psychiatr Epidemiol. 2016; 51: 203-210.

[9] Markkula N, Kivekäs T, Suvisaari J, et al. Employment status of depressed individuals in an 11-year follow-up: results from the Finnish Health 2011 Survey. J Occup Environ Med. 2017; 59: 603-608.

[10] Gutiérrez-Lobos K, Wölfl G, Scherer M, et al. The gender gap in depression reconsidered: the influence of marital and employment status on the female/male ratio of treated incidence rates. Soc Psychiatry Psychiatr Epidemiol. 2000; 35: 202-210.

[11] Ádám S, Nistor A, Nistor K, et al. Facilitating the diagnosis of depression and burnout by identifying demographic and workrelated risk and protective factors among nurses. [A kiégés és a depresszió diagnosztizálásának elősegítése demográfiai és munkahelyi védő- és kockázati tényezőik feltárásával egészségügyi szakdolgozók körében.] Orv Hetil. 2015; 156: 1288-1297. [Hungarian] 
[12] Miyake Y, Tanaka K, Arakawa M. Employment, income, and education and prevalence of depressive symptoms during pregnancy: the Kyushu Okinawa Maternal and Child Health Study. BMC Psychiatry 2012; 12: 117.

[13] Angstman KB, Rasmussen NH, MacLaughlin KL, et al. Interrelationship of functional status question of the PHQ-9 and depression remission after six months of collaborative care. J Psychiatr Res. 2013, 47: 418-422.

[14] Torzsa P, Szeifert L, Dunai K, et al. Diagnosis and therapy of depression in primary care. [A depresszió diagnosztikája és kezelése a családorvosi gyakorlatban.] Orv Hetil. 2009; 150: 1684-1693. [Hungarian]

[15] Sarfati D, Stewart K, Woo C, et al. The effect of remission status on work functioning in employed patients treated for major depressive disorder. Ann Clin Psychiatry 2017; 29: 11-16.

[16] Yeh MY, Lee Y, Sung SC, et al. Clinical predictors associated with full remission versus episode of major depressive disorder outpatients: the experience at a teaching hospital in Taiwan. BMC Psychiatry 2014, 14: 273.

[17] Hamilton M. A rating scale for depression. J Neurol Neurosurg Psychiatry 1960; 23: 56-62.

[18] Hamilton M. Development of a rating scale for primary depressive illness. Br J Soc Clin Psychol. 1967; 6: 278-296.

[19] Rózsa S, Szádóczky E, Schmidt V, et al. Psychometric characteristics of Hamilton Depression Rating Scale in depressed patients [A Hamilton Depresszió Skála pszichometriai jellemzői depressziós betegek körében.] Psychiatria Hung. 2003; 18: 251262. [Hungarian]

[20] Zimmerman M, Martinez JH, Young D, et al. Severity classification on the Hamilton depression rating scale. J Affect Disord. 2013; 150: 384-388.

[21] Riedel M, Möller HJ, Obermeier M, et al. Response and remission criteria in major depression - a validation of current practice. J Psychiatric Res. 2010; 44: 1063-1068.

[22] Lin CH, Chen CC, Wang FC, et al. Percentage reduction of depression severity versus absolute severity after initial weeks of treatment to predict final response or remission. Psychiatry Clin Neurosci. 2013, 67: 265-272.

[23] Balestri M, Calati R, Souery D, et al. Socio-demographic and clinical predictors of treatment resistant depression: a prospective European multicenter study. J Affect Disord. 2016; 189: 224232.

[24] De Carlo V, Calati R, Serretti A. Socio-demographic and clinical predictors of non-response/non-remission in treatment resistant depressed patients: A systematic review. Psychiatry Res. 2016; 240: 421-430.
[25] Iniesta R, Malki K, Maier W, et al. Combining clinical variables to optimize prediction of antidepressant treatment outcomes. J Psychiatr Res. 2016; 78: 94-102.

[26] Beam CR, Dinescu D, Emery R, et al. A twin study on perceived stress, depressive symptoms, and marriage. J Health Soc Behav. 2017; 58: 37-53.

[27] Trivedi MH, Morris DW, Pan JY, et al. What moderator characteristics are associated with better prognosis for depression? Neuropsychiatr Dis Treat. 2005; 1: 51-57.

[28] Perlis RH, Alpert J, Nierenberg AA, et al. Clinical and sociodemographic predictors of response to augmentation, or dose increase among depressed outpatients resistant to fluoxetine 20 $\mathrm{mg}$ /day. Acta Psychiatr Scand. 2003; 108: 432-438.

[29] Lagerveld SE, Bültmann U, Franche RL, et al. Factors associated with work participation and work functioning in depressed workers: A systematic review. J Occup Rehabil. 2010; 20: 275-292.

[30] Burr H, Rauch A, Rose U, et al. Employment status, working conditions and depressive symptoms among German employees born in 1959 and 1965. Int Arch Occup Environ Health 2015; 88: 731-741.

[31] Nistor K, Nistor A, Ádám S, et al. The relationship of work-related psychosocial risk factors with depressive symptoms among Hungarian workers. Preliminary results of the Hungarian Work Stress Survey. [Munkahelyi pszichoszociális kockázati tényezők kapcsolata a depressziós tünetegyüttessel a magyar munkavállalók körében. Az Országos Munkahelyi Stresszfelmérés előzetes eredményei.] Orv Hetil. 2015; 156: 439-448.

[32] Stankunas M, Kalediene R, Starkuviene S, et al. Duration of unemployment and depression: a cross-sectional survey in Lithuania. BMC Public Health 2006; 6: 174.

[33] Trivedi MH, Kurian BT, Grannemann BD. Clinical predictors in major depressive disorder. Primary Psychiatry 2007; 14: 47-53.

[34] Bulloch AG, Williams JV, Lavorato DH, et al. The relationship between major depression and marital disruption is bidirectional. Depress Anxiety 2009; 26: 1172-1177.

[35] Leuchter AF, Cook IA, Marangell LB, et al. Comparative effectiveness of biomarkers and clinical indicators for predicting outcomes of SSRI treatment in major depressive disorder: results of the BRITE-MD study. Psychiatry Res. 2009; 169: 124-131.

(Csibi Sándor dr., Koronka (Corunca), 231., 547367, Maros megye, Románia. e-mail: csibi.sandor@umftgm.ro)

\title{
A rendezvények és kongresszusok híranyagának leadása
}

\author{
a lap megjelenése előtt legalább 40 nappal lehetséges, a 6 hetes nyomdai átfutás miatt. \\ Kérjük megrendelőink szíves megértését.
}

A híranyagokat a következő címre kérjük:

Orvosi Hetilap titkársága: edit.budai@akademiai.hu

Akadémiai Kiadó Zrt. 